\title{
Extractor efficiency and critical phosphorus levels for establishing pasture in
} Amazonas

\author{
Marcelo Tavares Nunes ${ }^{1 *} \odot$, Rodrigo Rener Santos Martins ${ }^{1} \odot$, Carlos Alberto Franco Tucci' ${ }^{1}$,

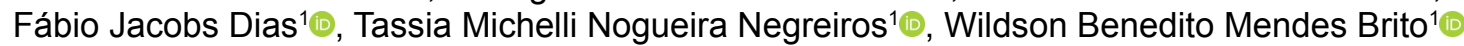 \\ ${ }^{1}$ Universidade Federal do Amazonas, Manaus, AM, Brasil. E-mail: mtn.zootecnista@gmail.com; drigo_rener@hotmail.com; tucci_ufam@hotmail.com; jacobsdias@ufam.edu.br; \\ tassiamichelli.tmnn@gmail.com; wild.brito@gmail.com
}

ABSTRACT: The Mehlich-1 extractor is the most used in Brazil, however it extracts low phosphorus (P) levels in soils with high clay levels and iron-bound $(\mathrm{Fe})$ and aluminum (Al) fractions. Thus, we aimed to evaluate the $\mathrm{P}$ availability and fertility classes in Yellow Latosol (YL) and Gleysol Haplicum (GH) soils using Mehlich-1, Mehlich-3 and anion exchange resin extractors, as well as to estimate the critical P levels in the soil and in plants for establishing Urochloa humidicola cv. Common. All extractors were efficient in evaluating the availability of $\mathrm{P}$ in the soil, however the anion exchange resin showed a high correlation with the $\mathrm{P}$ accumulation in the shoot, which can be considered the most efficient method in $\mathrm{P}$ extraction. However, we recommend the Mehlich-3 extractor due to its high efficiency in extracting the $\mathrm{P}$ linked to the $\mathrm{Fe}$ and $\mathrm{Al}$ fractions, in addition to being a multi-element extractor. The critical level of $P$ in the soil for establishing $U$. humidicola by Mehlich-3 in $\mathrm{YL}$ is $10.32 \mathrm{mg} \mathrm{dm}^{-3}$, while it is $7.46 \mathrm{mg}$ $\mathrm{dm}^{-3}$ in $\mathrm{GH}$. The critical P level in plants grown in YL is $1.20 \mathrm{mg} \mathrm{dm}^{-3}$, and it is $1.54 \mathrm{mg} \mathrm{dm}^{-3}$ in GH. The estimated phosphate doses can be recommended for cultivating $U$. humidicola and can serve as a reference for future research on correlating and calibrating $P$ doses.

Key words: anion exchange resin; availability of P; Mehlich-1; Mehlich-3; Urochloa humidicola cv. Common

\section{Eficiência de extratores e níveis críticos de fósforo para o estabelecimento de pastagem no Amazonas}

RESUMO: 0 extrator Mehlich-1 é o mais utilizado no Brasil, no entanto extrai baixos valores de fósforo (P) em solos com elevados teores de argila e frações de $\mathrm{P}$ ligada a ferro (Fe) e alumínio (Al). Assim, objetivamos avaliar a disponibilidade $\mathrm{e}$ as classes de fertilidade de $\mathrm{P}$ em Latossolo Amarelo e Gleissolo Háplico utilizando Mehlich-1, Mehlich-3 e resina troca de ânions, bem como estimar os níveis críticos de $\mathrm{P}$ no solo e na planta para o estabelecimento de Urochloa humidicola comum. Todos os extratores foram eficientes em avaliar a disponibilidade de $\mathrm{P}$ no solo, no entanto a resina troca de ânions apresentou elevada correlação com 0 acúmulo de $P$ na parte aérea. podendo ser considerada o método mais eficiente na extração de $P$. No entanto, recomendamos o extrator Mehlich-3, devido a sua alta eficiência em extrair o $\mathrm{P}$ ligado às frações de $\mathrm{Fe}$ e Al, além de ser extrator multielementar. O nível crítico de P no solo para estabelecimento de U. humidicola por Mehlich-3 no YL é 10,32 $\mathrm{mg} \mathrm{dm}^{-3}$ e no $\mathrm{GH}$ é $7,46 \mathrm{mg} \mathrm{dm}^{-3}$. Em plantas cultivadas em YL o nível crítico na planta é $1,20 \mathrm{mg} \mathrm{dm}^{-3}$ e no GH é $1,54 \mathrm{mg} \mathrm{dm}^{-3}$. As doses de fosfato estimadas podem ser recomendadas para o cultivo de $U$. humidicola e sevem como referência para futuras pesquisas de correlação e calibração de doses de P.

Palavras-chave: resina troca de ânions; disponibilidade de P; Mehlich-1; Mehlich-3; Urochloa humidicola comum

\footnotetext{
* Marcelo Tavares Nunes - E-mail: mtn.zootecnista@gmail.com (Corresponding author)

Associate Editor: Fernando José Freire
} 


\section{Introduction}

Mehlich-1 is one of the most widely used extractors in Brazil, effectively extracting $\mathrm{P}$ from $\mathrm{Al}, \mathrm{Fe}$ and $\mathrm{Ca}$ phosphates in acidic soils $(\mathrm{pH}<6.5)$ with low organic matter content and with low cation exchange capacity (Kabala et al., 2018). Underestimated values of $\mathrm{P}$ extracted by Mehlich-1 have been verified in clayey soils with a high $\mathrm{pH}$ due to its extraction power being worn out by the soil itself. The acidity in these soils is more buffered, thus the initial pH of 1.2 of Mehlich-1 is quickly elevated to values close to that of the soil (Novais et al., 2015). Likewise, the $\mathrm{SO}_{4}{ }^{2-}$ of the extractor which exchanges with the phosphate is also adsorbed by the soil in places not yet occupied by $P$, thereby losing extraction power (Freitas et al., 2013). On the other hand, overestimated levels of available $P$ have been verified in soils with a predominance of $P$-Ca due to the genesis of the soil or from using low reactivity natural phosphates.

Mehlich-3 is a multi-element extractor which is suitable for different types of soils, overcoming the limitations of Mehlich-1. The acetic acid solution is used to extract $P$, promoting dissolution of $\mathrm{Ca}$ phosphates, and the addition of ammonium fluoride releases more $P$ from the phosphates bound to Al through formation of Al-F complexes (Wuenscher et al., 2015). High applicability, correlation with other $P$ analysis methods, and a high correlation of $P$ extractions with crop yield are the most striking characteristics among the benefits of this method which that determine its use in the United States of America (USA), Canada (Kabala et al., 2018) and Southern Brazil (Mumbach et al., 2020).

The method based on anionic exchange resin enables evaluating labile $\mathrm{P}$ and is currently the method used in soil fertility laboratories in the State of São Paulo, Brazil (Freitas et al., 2013). The anion exchange resin works by removing the $P$ from the soil solution as the $P$ from the solid phase is released. The mechanism induces $P$ adsorption in the solution to the positive charges of the anionic anion exchange resin and consequently removes $\mathrm{P}$ adsorbed on the surface of the soil particles (Raij et al., 1986). The anionic resin acts similar to the role played by plants, removing $P$ from the soil, and is different from the extraction performed by acid and basic extractors.

Amazon soils are characterized by being tropical with low natural fertility, strongly acidic and having high levels of organic matter. They are highly weathered soils consisting of low-activity clay, silicate minerals type 1:1 and Fe and Al oxyhydroxides (Schaefer et al., 2008). Studies with extractors in soils with similar characteristics to Amazon soils show divergent results. Novais et al. (2015) found a decrease in $P$ extraction by Mehlich-1 in clay soils, while an opposite result was found by Mumbach et al. (2020), in which greater extractions were obtained by Mehlich-1. In a study by Arruda et al. (2015), the resin was more efficient than Mehlich-1 in evaluating the $\mathrm{P}$ content in the soil, and Mumbach et al. (2018) identified that Mehlich-3 and resin extractions were 11 to $12 \%$ higher than Mehlich-1 extractions. In this context, it is observed that the extractor efficiency does not exclusively depend on the characteristics of its constituents, but also on the soil properties.

Inappropriate use of the extractor may overestimate or underestimate the available $\mathrm{P}$ content. When obtaining overestimated $P$ values, the soil does not need fertilizer application, or it needs low concentrations to restore fertility. Thus, not applying $P$ concentrations or applying concentrations below nutritional requirements can lead the plant to present a nutritional deficiency status, reducing leaf expansion, leaf surface area and number of leaves (Taiz et al., 2017). Underestimated determinations of $P$ content in the soil can lead to $P$ applications which are above nutritional requirements, thereby increasing production costs, decreasing the efficiency of fertilizer use, in addition to causing environmental problems such as eutrophication of water bodies (Wu et al., 2020).

The fertilization recommendation for Amazon soils is based on studies from other regions of Brazil, and there is no specific fertilizer recommendation manual or bulletin. In this sense, there is a need for studies with methods to determine the $P$ availability and critical levels for the Amazon soils, as well as to identify the most efficient extractor in estimating the $P$ levels in the soil, and then based on the estimated levels it will be possible determine the $P$ critical levels and fertility classes in the region.

As Mehlich-1 extracts little $P$ in soils with high clay contents and recovering low fractions of $P$ linked to Fe and $\mathrm{Al}$ in the soil (Brito Neto et al., 2017), our hypothesis is that the Mehlich-1 efficiency will be lower in soils with high clay and organic matter levels (which are predominant characteristics in Amazon soils) than the Mehlich-3 efficiency and anion exchange resin. Thus, we aimed to evaluate the $P$ availability and fertility classes in Yellow Latosol and Gleysol Haplicum soils using Mehlich-1, Mehlich-3 and anion exchange resin, as well as to estimate the critical levels of $P$ in the soil and in the plant for establishing Urochloa humidicola cv. Common.

\section{Materials and Methods}

\section{Species and growing conditions}

Urochloa humidicola cv. Common plants were grown in plastic polyethylene pots using soil as a substrate. The work was conducted in a greenhouse with natural light and environmental conditions with an average temperature of $32.7^{\circ} \mathrm{C}$, relative humidity of $63 \%$ and a photoperiod of 12:00 h/12: $00 \mathrm{~h}$ (day/night). The study was performed at the Department of Engineering and Soils of the Faculty of Agricultural Sciences of the Federal University of Amazonas (FCA/UFAM), Manaus-AM, from January to August 2015.

\section{Experimental design}

We used a randomized block design with five repetitions. We applied $\mathrm{P}_{2} \mathrm{O}_{5}$ (phosphorus pentoxide) doses to the soil to assess the extractor efficiency, with the treatments consisting of seven doses of $\mathrm{P}_{2} \mathrm{O}_{5}$. The doses were equivalent to $0,30,60,120,150,180$ and $210 \mathrm{~kg} \mathrm{ha}^{-1}$ of $\mathrm{P}_{2} \mathrm{O}_{5}$, totaling 35 
experimental units for each soil. Doses were stipulated based on the remaining P-content and the clay content (Table 1) as recommended by Ribeiro et al. (1999), adopting the high technological level according to Cantarutti et al. (2007).

\section{Specific procedures}

\section{Obtaining and characterizing the soil}

The soils surveyed were classified as Yellow Latosol (YL) and Gleysol Haplicum (GH) (Santos et al., 2006), with sampling being carried out in September 2014. The YL is located in an area of solid land covered by shallow scrub, and the $\mathrm{GH}$ in a lowland area under pasture. The superficial layer from 0 to 20 $\mathrm{cm}$ deep was sampled in both soils. The YL is located on the banks of the AM-254, Km 63, at the geographic coordinates 3o 31' 37.4" S and 590 46' 28.05" W. The GH is located on the banks of $\mathrm{Br}-319, \mathrm{Km} \mathrm{75}$, at the geographic coordinates of 30 31' 37.4" S and 59 46' 28.05" W and 0345'3.44" S 60 17' 39.91" W. The soil was homogenized after collection, sieved in a $4 \mathrm{~mm}$ mesh and air-dried. Sub-samples were collected and passed through $2 \mathrm{~mm}$ meshes in order to obtain the Air-Dried Fine Earth (ADFE).

\section{Soil correction and application of treatments}

Soil analyzes were performed according to the methodology by Silva (2009) at the FCA Soil Laboratory and are shown in Table 1. We took into account the P-remaining content of the soils to interpret the $P$ availability (Ribeiro et al., 1999). Based on the content of the P-remnant of $\mathrm{YL}$ and $\mathrm{GH}$, the obtained

Table 1. Characterization of chemical, textural and fractional attributes of $P$ from $Y L$ and $G H$.

\begin{tabular}{|c|c|c|}
\hline Soil attributes & $\overline{Y L}$ & $\overline{\mathrm{GH}}$ \\
\hline $\mathrm{pH}\left(\mathrm{CaCl}_{2}\right)$ & 3.9 & 3.8 \\
\hline$P\left(\mathrm{mg} \mathrm{dm}^{-3}\right)^{1}$ & 2 & 2 \\
\hline$P$ rem $\left(\mathrm{mg} \mathrm{dm}^{-3}\right)^{2}$ & 7.1 & 6.8 \\
\hline 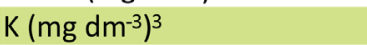 & 20 & 30 \\
\hline $\mathrm{Ca}^{2+}\left(\mathrm{cmol}_{\mathrm{c}} \mathrm{dm}^{-3}\right)^{4}$ & 0.56 & 1.22 \\
\hline $\mathrm{Mg}^{2+}\left(\mathrm{cmol}_{\mathrm{c}} \mathrm{dm}^{-3}\right)^{5}$ & 0.28 & 0.7 \\
\hline $\mathrm{Al}^{3+}\left(\mathrm{cmol}_{\mathrm{C}} \mathrm{dm}^{-3}\right)^{6}$ & 5.0 & 15.0 \\
\hline $\mathrm{H}+\mathrm{Al}\left(\mathrm{cmol}_{\mathrm{c}} \mathrm{dm}^{-3}\right)^{7}$ & 10.9 & 29.7 \\
\hline $\mathrm{SB}\left(\mathrm{cmol}_{\mathrm{c}} \mathrm{dm}^{-3}\right)^{8}$ & 0.89 & 1.98 \\
\hline $\mathrm{m}(\%)^{9}$ & 84.89 & 88.34 \\
\hline $\mathrm{t}\left(\mathrm{cmol}_{\mathrm{c}} \mathrm{dm}^{-3}\right)^{10}$ & 5.89 & 16.98 \\
\hline $\mathrm{T}\left(\mathrm{cmol}_{\mathrm{c}} \mathrm{dm}^{-3}\right)^{11}$ & 11.79 & 31.68 \\
\hline$V(\%)^{12}$ & 7.55 & 6.25 \\
\hline Clay $\left(\mathrm{g} \mathrm{kg}^{-1}\right)$ & 84.89 & 88.34 \\
\hline $\operatorname{SOM}\left(\mathrm{g} \mathrm{kg}^{-1}\right)^{13}$ & 40.9 & 10.20 \\
\hline Texture ${ }^{14}$ & MA & AG \\
\hline P-labile $\left(\mathrm{NH}_{4} \mathrm{Cl}\right)\left(\mathrm{mg} \mathrm{dm}^{-3}\right)^{16}$ & $\mathrm{Nd}^{*}$ & $\mathrm{Nd}^{*}$ \\
\hline P-Al $\left(\mathrm{NH}_{4} \mathrm{~F}\right)\left(\mathrm{mg} \mathrm{dm}^{-3}\right)^{17}$ & 61.89 & 65.48 \\
\hline $\mathrm{P}-\mathrm{Fe}(\mathrm{NaOH})\left(\mathrm{mg} \mathrm{dm}^{-3}\right)^{18}$ & 50.92 & 233.15 \\
\hline $\mathrm{P}-\mathrm{Ca}\left(\mathrm{H}_{2} \mathrm{SOH}\right)\left(\mathrm{mg} \mathrm{dm}^{-3}\right)^{19}$ & 49.31 & 43.68 \\
\hline P-Total (Sum) (mg dm-3)20 & 162.12 & 342.31 \\
\hline
\end{tabular}

Mehlich-1 extractor, ${ }^{1} \mathrm{P}$ : phosphorus available, ${ }^{2} \mathrm{P}$ rem: remaining phosphorus, ${ }^{3} \mathrm{~K}$ : potassium available, ${ }^{4} \mathrm{Ca}^{2+}$ : exchangeable calcium, ${ }^{5} \mathrm{Mg}^{2+}$ : exchangeable magnesium, ${ }^{6} \mathrm{Al}^{\beta^{+*}}$ : exchangeable aluminum, ${ }^{7} \mathrm{H}+\mathrm{Al}$ : potential acidity, ${ }^{8} \mathrm{SB}$ : base sum, ${ }^{9} \mathrm{~m}$ : aluminum saturation percentage, ${ }^{10} \mathrm{t}$ : effective cation exchange capacity, ${ }^{11} \mathrm{~T}$ : cation exchange capacity at $\mathrm{pH} 7$, ${ }^{12} \mathrm{~V}$ : percentage of base saturation, ${ }^{13} \mathrm{SOM}$ : soil organic matter, ${ }^{14} \mathrm{Texture}$ : AG: Clayey, MA: Very clayey (Santos et al., 2006), ${ }^{16} \mathrm{P}$-labile: labile phosphorus, ${ }^{17} \mathrm{P}$-Al: phosphorus bonded to aluminum, ${ }^{18} \mathrm{P}-\mathrm{Fe}$ : phosphorus bound to iron, ${ }^{19} \mathrm{P}$-Ca: phosphorus bound to calcium, ${ }^{20} \mathrm{P}$-Total: total phosphorus, $\mathrm{Nd}^{*}$ - not detected.
$P$ levels were classified as very low. Thus, the $P$ availability in the soil will not supply the nutritional requirement of $P$ by the plant, presenting symptoms of $\mathrm{P}$ deficiency in the future.

The modified method of Chang \& Jackson (1957) was used to determine the P-labile, $\mathrm{P}$ bound to aluminum (P-AI), $P$ bound to iron ( $P-F e$ ) and $P$ bound to calcium ( $P-C a$ ) fractions in order to characterize the $P$ fractions in the soil. Thus, $0.5 \mathrm{~g}$ of soil (ADFE) was added into a $125 \mathrm{ml}$ erlenmeyer containing $25 \mathrm{ml}$ of $\mathrm{NH} 4 \mathrm{Cl} 1 \mathrm{~mol} \mathrm{~L}^{-1}$ followed by stirring for $30 \mathrm{~min}$. The suspension was centrifuged for $5 \mathrm{~min}$ at 1,800 rpm, then the supernatant was filtered on paper $(<0.45 \mu \mathrm{m})$ and transferred to a $50 \mathrm{ml}$ volumetric flask and filled with deionized water, from which the $P$ concentration was determined and the soil P-labile content was calculated.

The soil residue from the P-labile extraction was transferred to a $125 \mathrm{~mL}$ conical flask and $25 \mathrm{~mL}$ of $\mathrm{NH}_{4} \mathrm{~F} 0.5$ $\mathrm{mol} \mathrm{L}^{-1}$ ( $\mathrm{pH}$ 8.2) was added, followed by stirring for an hour. Next, the suspension was centrifuged for $5 \mathrm{~min}$ at $1,800 \mathrm{rpm}$, and the supernatant was filtered on paper $(<0.45 \mu \mathrm{m})$ and transferred to a $50 \mathrm{~mL}$ volumetric flask. The soil residue was subjected to double washing with $12.5 \mathrm{ml}$ of saturated $\mathrm{NaCl}$ and then centrifuged. These washing solutions were mixed with the extract, and the volume was completed to $50 \mathrm{~mL}$ with deionized water, then determining the $P$ concentration and calculating the P-Al content in the soil.

The soil residue from the $\mathrm{P}$-Al extraction was transferred to a $125 \mathrm{~mL}$ conical flask to which $25 \mathrm{~mL}$ of $\mathrm{NaOH} 0.1 \mathrm{~mol} \mathrm{~L}^{-1}$ was added and then stirred for $17 \mathrm{~h}$. After that period, the suspension was centrifuged for $5 \mathrm{~min}$ at $1,800 \mathrm{rpm}$, and the supernatant was filtered on paper $(<0.45 \mu \mathrm{m})$ and transferred to a $50 \mathrm{~mL}$ volumetric flask. The soil residue was subjected to double washing with concentrations of $12.5 \mathrm{~mL}$ of saturated $\mathrm{NaCl}$ and then centrifuged. These washing solutions were mixed with the extract, and the volume was made up to $50 \mathrm{ml}$ with deionized water. Next, $4 \mathrm{~mL}$ of $\mathrm{H}_{2} \mathrm{SO}_{4} 1 \mathrm{~mol} \mathrm{~L}^{-1}$ was added to eliminate the turbidity of the extract, followed by shaking it with a glass stick. Then, the extract was centrifuged again for $5 \mathrm{~min}$ at $1,800 \mathrm{rpm}$ and filtered on paper $(<0.45 \mu \mathrm{m})$ to obtain a clear extract, and transferred to a $50 \mathrm{~mL}$ volumetric flask. Finally, the $P$ concentration in the extract was determined and the P-Fe content in the soil was calculated.

The soil residue from the P-Fe extraction was transferred to a $125 \mathrm{~mL}$ conical flask to which $25 \mathrm{~mL}$ of $\mathrm{H}_{2} \mathrm{SO}_{4} 0.25 \mathrm{~mol} \mathrm{~L}^{-1}$ was added, followed by stirring the suspension for one hour. The suspension was then centrifuged for $10 \mathrm{~min}$ at 1,800 rpm and filtered on paper $(<0.45 \mu \mathrm{m})$, and the supernatant transferred to a $50 \mathrm{~mL}$ volumetric flask. The soil residue was washed twice with $12.5 \mathrm{ml}$ portions of saturated $\mathrm{NaCl}$ and then the suspension was centrifuged. These washing solutions were mixed with the extract, and the volume was adjusted to $50 \mathrm{~mL}$ with deionized water. The $\mathrm{P}$ concentration in extract $\mathrm{D}$ was subsequently determined and the P-Ca content in the soil was calculated.

The $\mathrm{P}$ dosage in the extracts was done by colorimetry. The P-total was obtained by summing the P-labile, P-Al, P-Fe and $\mathrm{P}-\mathrm{Ca}$ levels, and are presented in Table 1 . A calcium carbonate 
$\left(\mathrm{CaCO}_{3}\right)$ and magnesium carbonate $\left(\mathrm{MgCO}_{3}\right)$ mixture in a $4: 1$ $\mathrm{Ca}: \mathrm{Mg}$ stoichiometric ratio was used to correct the soil acidity. Next, the samples were incubated for 30 days in pots with a capacity of $3 \mathrm{dm}^{-3}$ in order to increase base saturation to $40 \%$ according to Cantarutti et al. (2007), maintaining humidity at $80 \%$ of the total pore volume, and using the gravimetric method to determine the field capacity of the soil.

Basic fertilization was carried out as recommended by Malavolta (1980). The macro and micronutrient doses expressed in $\mathrm{mg} \mathrm{dm}^{-3}$ of soil were: $100,100,40,5,1.5,3.6,0.8$ and 0.15 for $\mathrm{N}, \mathrm{K}, \mathrm{S}, \mathrm{Zn}, \mathrm{Cu}, \mathrm{Mn}, \mathrm{B}$ and Mo, respectively. The nitrogen and potassium fertilization were divided into 3 (three) times using urea and potassium chloride as the sources, and applying 71.47 and 63.57 respectively. The first application was carried out during the sowing, the second was carried out during the uniform tiller cut, and the last in the first evaluation tiller cut at 30 days, with cutting height $10 \mathrm{~cm}$ above the soil.

The liming was applied in solid form while applying the treatments corresponding to the phosphate doses (phosphoric acid $\left(\mathrm{H}_{3} \mathrm{PO}_{4}\right)$ p.a), and basic fertilization was performed in the form of solution. After applying the treatments and basic fertilization, the soils were incubated again for a period of 30 days. All applications were carried out with pure reagents for analysis (p.a.).

Mehlich-1, Mehlich-3 and anion exchange resin in the chemical evaluation of $\mathrm{P}$ available in the soil

Simple soil samples were collected in each pot using a probe-type auger at the end of the incubation phase and before sowing, thus obtaining a sample composed by treatment. Next, $100 \mathrm{~g}$ of ADFE were collected from the experimental plots to determine the $\mathrm{P}$ extraction available by the extractors: Mehlich-1 $\left(\mathrm{HCl} 0.05 \mathrm{~mol} \mathrm{~L}^{-1}+\mathrm{H}_{2} \mathrm{SO}_{4} 0.0125 \mathrm{~mol}\right.$ $\left.\mathrm{L}^{-1}\right)$, Mehlich-3 $\left(\mathrm{NH}_{4} \mathrm{~F} 0.015 \mathrm{~mol} \mathrm{~L}^{-1}+\mathrm{CH}_{3} \mathrm{COOH} 0.2 \mathrm{~mol} \mathrm{~L} \mathrm{~L}^{-1}+\right.$ $\mathrm{NH}_{4} \mathrm{NO}_{3} 0.25 \mathrm{~mol} \mathrm{~L}^{-1}+\mathrm{HNO}_{3} 0.013 \mathrm{~mol} \mathrm{~L}^{-1}+$ EDTA $0.001 \mathrm{~mol} \mathrm{~L}^{-1}$ ) and anion exchange resin. The quantification of the available $P$ was performed as recommended by Silva (2009).

\section{Conducting the experiment and irrigation}

Pure and viable seeds inlaid with B. humidicola (Syn. U. humidicola) with a cultural value (VC) of $25 \%$ were used for sowing. Approximately 10 seeds were added per pot. Periodic thinning was carried out after germination to obtain the density of three tillers per pot. Soil moisture was maintained at around $80 \%$ of the total pore volume while conducting the experiment through daily weighing of the pots and adding deionized water.

The plant shoots were uniformly cut at 30 days after seedling emergence. The first evaluation cut (C1) was performed at 45 days after uniformity and the second cut (C2) at 90 days after uniformity. All cuts, including uniformity, were made $10 \mathrm{~cm}$ above the soil surface.

\section{Evaluation of the experiment}

Dry mass production

The last evaluation cut of the plant shoots was performed at 90 days. The shoot components were separated into stems, more sheaths and leaf blades after cutting. Then the components were washed with deionized water and dried in an oven with forced air circulation at a temperature of 55으 until the mass reached constant weight. The components were subsequently weighed on a scale with an accuracy of $0.001 \mathrm{~g}$ and added together to obtain the shoot dry matter (SDM).

\section{Extractor efficiency, critical levels of $\mathrm{P}$ and fertility classes}

The extractors were evaluated through the correlation coefficient using the accumulated $P$ content in the shoot and correlating them with the $P$ available in the soil by the Mehlich-1, Mehlich-3 and anion exchange resin extractors (Alvarez, 1996). The SDM was submitted to nitric-perchloric digestion to determine the $P$ content. Next, the $P$ accumulation in the shoot was obtained from the multiplication result of the SDM production and the $P$ levels in the plant (Silva, 2009).

The SDM production results for each experimental unit were adjusted according to the $P$ levels $\left(\mathrm{mg} \mathrm{dm}^{-3}\right)$ extracted from the soil by the different extractors. Quadratic regression models were subsequently adjusted in which the dependent variable was the SDM productivity and the independent variable was the $P$ content in the soil.

The $P$ values in the soil were calculated based on the first and second derivatives of the equations, which provided maximum physical efficiency (MPE). Thus, the fertility classes of $P$ levels in the soil were established with the equations and considering the MPE as $100 \%$. The fertility classes correspond to a very low level with relative yields below $50 \%$; low level with relative productions between $50 \%$ and $70 \%$; medium level with relative production between $70 \%$ and $90 \%$; high level with relative productions between $90 \%$ and $100 \%$; and very high level when the $P$ levels were higher than necessary to reach production above $100 \%$ (Alvarez, 1996).

The phosphate doses in the quadratic regression models were considered an independent variable and the SDM production the dependent variable, from which we estimated the maximum economic efficiency (MEE) dose as corresponding to $90 \%$ of MPE. Maximum productivity (MP) was determined when estimating the dose corresponding to MPE, and we estimated the productivity corresponding to $90 \%$ of MP with MEE. The critical levels of $P$ in the soil for each extractor were obtained by replacing the dose corresponding to MEE in the linear regression models of the $P$ contents extracted by Mehlich-1, Mehlich-3 and anion exchange resin. The critical $P$ level in the plant was estimated to replace the MEE dose in the linear regression model of the $P$ levels in the plant (Alvarez, 1996).

\section{Data analysis}

The data were subjected to a normality and homogeneity test. In accordance with the principles of normal distribution and homogeneity, the SDM production and the $P$ levels extracted in the soil and in the plant were subjected to analysis of variance (ANOVA). Linear and quadratic regression models were adjusted when significant by the $\mathrm{F}$ test at the $5 \%$ probability level. 
The correlation of $\mathrm{P}$ content in the soil obtained by the extractors related to the $\mathrm{P}$ content in the shoot, SDM production and $P$ accumulation in the shoot were used to select the most efficient extractor in estimating the $P$ availability in the soil. The correlation strength was interpreted according to Evans (1996), in which: <0.19, 0.2-0.39, 0.4-0.59, 0.6-0.79 and 0.8-1 are classified as very weak, weak, moderate, strong and very strong, respectively.

The variance and regression analyzes were performed using the STATISTICA Application 13 software program. The comparison between cuts $1\left(C_{1}\right)$ and $2\left(C_{2}\right)$ and the Mehlich-1, Mehlich-3 and anion exchange resin extractions was performed based on the angular coefficients of the adjusted equation between the dependent variable as a function of the applied phosphate doses.

\section{Results}

\section{Extractions of $\mathrm{P}$ available in the soil}

We observed a greater recovery of $P$ in Mehlich-3 in both soils based on the angular coefficients of the equations. However, the Mehlich-1 recovery was less than the anion exchange resin in $\mathrm{YL}$ and greater in $\mathrm{GH}$ (Table 2).

Table 2. Regression equation for $P$ content in the soil $\left(\mathrm{mg} \mathrm{dm}^{-3}\right)$ recovered by the Mehlich-1, Mehlich-3 and anion exchange resin extractors as a dependent variable of $\mathrm{P}_{2} \mathrm{O}_{5}$ doses applied for Yellow Latosol (YL) and Gleysol Haplicum (GH) soils.

\begin{tabular}{|c|c|c|c|}
\hline Soil & Extractor & Regression equation & $\mathrm{R}^{2}$ \\
\hline \multirow{3}{*}{ YL } & Mehlich-1 & $\hat{Y}=1.5467+0.0272^{* * P}$ & 0.98 \\
\hline & Mehlich-3 & $\hat{Y}=1.9240+0.0976^{* * P}$ & 0.99 \\
\hline & Anion exchange resin & $\hat{Y}=1.6706+0.0452^{* * P}$ & 0.98 \\
\hline \multirow{3}{*}{$\mathrm{GH}$} & Mehlich-1 & $\hat{Y}=0.5121+0.0419 * * P$ & 0.98 \\
\hline & Mehlich-3 & $\hat{Y}=0.2538+0.0548 * * P$ & 0.99 \\
\hline & Anion exchange resin & $\hat{Y}=0.7106+0.0333^{* * P}$ & 0.97 \\
\hline
\end{tabular}

** and $*$ Significant to the $1 \%$ to $5 \%$ level of probability, respectively.

Dry matter production of $U$. humidicola as a function of $\mathrm{P}$ doses

There was an increase in the production of SDM due to the phosphate doses in both cuts and in the sum of the cuts. The angular coefficients for the SDM production were higher in $\mathrm{C}_{1}$ compared to $\mathrm{C}_{2}$ in both soils (Table 3 ). We observed that the highest doses of MPE, MEE, MP and $90 \%$ MP were obtained in $\mathrm{C}_{1}$ in relation to $\mathrm{C}_{2}$ (Table 3 ).

\section{Selection of extractors}

The $\mathrm{P}$ content recovered by extractors showed a positive correlation with dry matter production, $P$ content and $P$ accumulation in the shoot. The correlation between $P$ levels obtained by the extractors and the $P$ accumulation in the shoot was considered for selecting the extractor. The anion exchange resin showed the highest correlation coefficients ( $r$ $=0.91 \mathrm{YL}$ and $0.89 \mathrm{GH}$ ) among the tested extractors, followed by Mehlich-3 $(r=0.89 \mathrm{YL}$ and $0.88 \mathrm{GH})$ and Mehlich-1 $(r=0.86$ YL and $0.85 \mathrm{GH}$ ) (Table 4).

Table 4. Linear correlation ( $r$ ) matrix between the phosphorous contents in soils extracted by Mehlich-1, Mehlich-3 and anion exchange resin extractors with the $P$ contents in the plant, shoot dry matter (SDM) and P content for YL and GH soils.

\begin{tabular}{|c|c|c|c|c|c|c|}
\hline Soil & Variables & Mehlich-1 & Mehlich-3 & $\begin{array}{c}\text { Anion } \\
\text { exchange } \\
\text { resin }\end{array}$ & $\begin{array}{l}\text { P content } \\
\left(\mathrm{g} \mathrm{kg}^{-1}\right)\end{array}$ & SDM \\
\hline YL & \multirow{2}{*}{ Mehlich-3 } & $0.93 * *$ & & & & \\
\hline $\mathrm{GH}$ & & $0.81^{* *}$ & & & & \\
\hline YL & \multirow{2}{*}{$\begin{array}{l}\text { Anion } \\
\text { exchange } \\
\text { resin }\end{array}$} & $0.95^{* *}$ & $0.97^{* *}$ & & & \\
\hline $\mathrm{GH}$ & & $0.74^{* *}$ & $0.80^{* *}$ & & & \\
\hline $\mathrm{YL}$ & \multirow{2}{*}{$\begin{array}{l}\text { P content } \\
\left(\mathrm{g} \mathrm{kg}^{-1}\right)\end{array}$} & $0.88 * *$ & $0.92 * *$ & $0.93^{* *}$ & & \\
\hline $\mathrm{GH}$ & & $0.84^{* *}$ & $0.86 * *$ & $0.90 * *$ & & \\
\hline $\mathrm{YL}$ & \multirow{2}{*}{ DMAP } & $0.75^{* *}$ & $0.73^{* *}$ & $0.77^{* *}$ & $0.82 * *$ & \\
\hline $\mathrm{GH}$ & & $0.79 * *$ & $0.82 * *$ & $0.85^{* *}$ & $0.92 * *$ & \\
\hline $\mathrm{YL}$ & \multirow{2}{*}{$\begin{array}{l}\text { P content } \\
\text { (mg vase }^{-1} \text { ) }\end{array}$} & $0.86 * *$ & $0.89 * *$ & $0.91^{* *}$ & $0.98 * *$ & $0.87 * *$ \\
\hline $\mathrm{GH}$ & & $0.85 * *$ & $0.88^{* * *}$ & $0.89 * *$ & $0.97 * *$ & $0.92 * *$ \\
\hline
\end{tabular}

**Significant to the $1 \%$ level of probability.

P Critical levels and fertility classes for Mehlich-1, Mehlich-3 and anion exchange resin extractors

Higher critical levels of $\mathrm{P}$ are related to a greater recovery capacity of the extractor. Higher critical levels were obtained in Mehlich-3 in both soils. The anion exchange resin presented a higher critical level than Mehlich-1 in YL, while the Mehlich-1 critical level was higher than that obtained by the anion exchange resin in $\mathrm{GH}$ (Table 5).

From the productivity relative to 50,70, 90, 100 and > $100 \%$, the fertility classes of $P$ were established for planting $U$. humidicola in both soils (Table 6). The highest $\mathrm{P}$ levels in the fertility classes were obtained in Mehlich-3 in both soils.

\section{Critical $\mathrm{P}$ levels in the plant}

The $\mathrm{P}$ content and accumulation in the shoot was positively influenced by the phosphate doses applied to the

Table 3. Regression equations for shoot dry matter (SDM) (g vase $\left.{ }^{-1}\right)$ in cut $1\left(C_{1}\right)$, cut $2\left(C_{2}\right)$ and $C_{1}+C_{2}$ as a dependent variable of $\mathrm{P}_{2} \mathrm{O}_{5}\left(\mathrm{~kg} \mathrm{ha}^{-1}\right)$ applied in Yellow Latosol (YL) and Gleysol Haplicum (GH) soils.

\begin{tabular}{|c|c|c|c|c|c|c|c|}
\hline \multirow{2}{*}{ Soil } & \multirow{2}{*}{$\begin{array}{l}\text { Dry matter } \\
\text { production }\end{array}$} & \multirow{2}{*}{ Equation } & \multirow{2}{*}{$\mathbf{R}^{\mathbf{2}}$} & MPE & MEE & MP & $90 \% \mathrm{MP}$ \\
\hline & & & & \multicolumn{2}{|c|}{ kg ha-1 of $\mathrm{P}_{2} \mathrm{O}_{5}$} & \multicolumn{2}{|c|}{ g vase $^{-1}$} \\
\hline \multirow[b]{2}{*}{$\mathrm{YL}$} & SDM & $C_{1} \hat{Y}=2.3762+0.0577^{* * P}-0.0002 * * p^{2}$ & 0.98 & 144 & 87 & 6.54 & 5.89 \\
\hline & SDM & $C_{2} \hat{Y}=1.6356+0.0290 * * p-0.00007 * p^{2}$ & 0.99 & 207 & 126 & 4.64 & 4.18 \\
\hline \multirow[b]{2}{*}{$\mathrm{GH}$} & SDM & $C_{1} \hat{Y}=1.1032+0.08810 * * p-0.00026 * p^{2}$ & 0.97 & 171 & 113 & 8.63 & 7.77 \\
\hline & SDM & $C_{2} \hat{Y}=0.8180+0.0275^{* * P}$ & 0.98 & 210 & 186 & 6.59 & 5.93 \\
\hline
\end{tabular}

** and * Significant to $1 \%$ to $5 \%$ of probability, respectively. Maximum Physical Efficiency (MPE), Maximum Economic Efficiency (MEE), Maximum Production (MP) and $90 \%$ of Maximum Production ( $90 \% \mathrm{MP}$ ). 
Table 5. Critical levels of phosphorous in Yellow Latosol (YL) and Gleysol Haplicum (GH) soils for establishing U. humidicola cv. Common.

\begin{tabular}{lcc}
\hline \multicolumn{1}{c}{ Extractor } & Soil & Critical soil level $\left(\mathrm{mg} \mathrm{dm}^{-3}\right)$ \\
\hline \multirow{2}{*}{ Mehlich-1 } & $\mathrm{YL}$ & 3.89 \\
\multirow{2}{*}{ Mehlich-3 } & $\mathrm{GH}$ & 6.02 \\
\multirow{2}{*}{ Anion exchange resin } & $\mathrm{YL}$ & 10.32 \\
& $\mathrm{GH}$ & 7.46 \\
& $\mathrm{YL}$ & 5.56 \\
\hline
\end{tabular}

soil (Table 7). The $\mathrm{P}$ accumulation in the shoot was influenced by the increase of the $P$ content in the plant tissue and by the increase of the SDM production. The critical levels of $P$ in the shoot varied between soils, however they are within the reference range for Urochloa (1.0 to $1.50 \mathrm{~g} \mathrm{~kg}^{-1}$ of P) (Cantarutti et al., 2007).

\section{Discussion}

\section{Extractions of $\mathrm{P}$ available in the soil}

$\mathrm{P}$ linked to $\mathrm{Al}$ and Fe fractions predominate in the studied soils (Table 1).Thus, the greater recovery by Mehlich-3 (Table 2 ) in these conditions is attributed to the acidic $\mathrm{pH}$ of the extractor and the action of the fluoride ion acting efficiently in forming a complex with $\mathrm{Al}$ ions, thus releasing more phosphate bound to the metal (Wuenscher et al., 2015; Rosan et al., 2018). The $P$ retention added to the soil occurs both by the precipitation of $P$ in solution and by the ionic forms of $\mathrm{Fe}, \mathrm{Al}$ and $\mathrm{Ca}$, in addition to the $\mathrm{P}$ adsorption in $\mathrm{Al}$ and $\mathrm{Fe}$ oxydroxides present in tropical soils (Gou et al., 2020).

Lower values of available $P$ were obtained by Mehlich-1 in YL (Table 2). YL is characterized by having high organic matter and clay levels (Tables 1 and 2), which are predominant in Amazon soils. Mehlich-1 decreases its performance in high organic matter levels (Kabala et al., 2018), corroborating the results found in this study. Organic matter can influence the dynamics of $\mathrm{P}$ adsorption in soil in different ways, thus contributing to the predominance of amorphous minerals and having greater reactivity with the soil or reducing adsorption through the release of humic compounds which block adsorption sites (Mumbach et al., 2020).

Regarding the clay content, underestimated values of $P$ extracted by Mehlich-1 were verified in clayey soils like YL (Table 1). the soil constituents wore out the Mehlich-1 extraction power under these conditions. We emphasize that $P$ readsorption in the soil particles can occur during the resting time in the $P$ extraction by Mehlich-1, thus obtaining low concentrations of available P (Freitas et al., 2013; Mumbach et al., 2018).

The initial $\mathrm{pH}$ of 1.2 for Mehlich-1 in clayey soils like $\mathrm{YL}$ with more buffered acidity is rapidly elevated to values close to that of the soil (Novais et al., 2015). Therefore, the $\mathrm{SO}_{4}{ }^{2-}$ of the extractor which exchanges with the phosphate is also adsorbed by the soil in sites not yet occupied by $\mathrm{P}$, losing the extraction power (Freitas et al., 2013). The P extractions by Mehlich-1 in GH were superior to the anion exchange resin extractions (Table 2). The $\mathrm{GH}$ is characterized by presenting clay texture and low organic matter levels (Table 1), and Mehlich-1 effectively extracts the P contents from the soil in

Table 6. Interpretation classes of phosphorous availability for establishing U. humidicola cv. Common for Yellow Latosol (YL) and Gleysol Haplicum (GH) soils in the Mehlich-1, Mehlich-3 and resin extractors relative productivity \% (RP\%); VL: very low, L: low, $\mathrm{M}$ : medium, $\mathrm{H}$ : high, $\mathrm{VH}$ : very high.

\begin{tabular}{|c|c|c|c|c|c|c|}
\hline Extractor & Class & RP\% & $\begin{array}{l}\text { Productivity } \\
\left.\text { (g vase }{ }^{-1}\right)\end{array}$ & $\begin{array}{c}\text { Dose } \\
\left(\mathrm{kg} \mathrm{ha}^{-1}\right) \mathrm{YL} \text { and GH}\end{array}$ & $\begin{array}{c}\text { P Content } \\
\left.\text { (mg dm }{ }^{-3} \mathrm{YL}\right) \\
\end{array}$ & $\begin{array}{c}\text { P Content } \\
\left(\mathrm{mg} \mathrm{dm}^{-3} \mathrm{GH}\right)\end{array}$ \\
\hline \multirow{4}{*}{ Mehlich-1 } & $\mathrm{VL}$ & $0-50$ & 5.14 & 13.63 & $0-1.92$ & $0-2.52$ \\
\hline & L & $50-70$ & 7.19 & 43.13 & $1.92-2.72$ & $2.52-3.95$ \\
\hline & $\mathrm{H}$ & $90-100$ & 10.28 & 144.5 & $3.89-5.48$ & $6.02-8.85$ \\
\hline & VH & $>100$ & $>10.28$ & $>144.50$ & $>5.48$ & $>8.85$ \\
\hline \multirow[t]{3}{*}{ Mehlich-3 } & $M$ & $70-90$ & 9.25 & 85.97 & $6.13-10.32$ & $4.74-7.46$ \\
\hline & $\mathrm{H}$ & $90-100$ & 10.28 & 144.5 & $10.32-16.03$ & $7.46-11.16$ \\
\hline & VH & $>100$ & $>10.28$ & $>144.50$ & $>16.03$ & $>11.16$ \\
\hline \multirow{3}{*}{$\begin{array}{l}\text { Anion } \\
\text { exchange } \\
\text { resin }\end{array}$} & VL & $0-50$ & 5.14 & 13.63 & $0-2.29$ & $0-2.31$ \\
\hline & L & $50-70$ & 7.19 & 43.13 & $2.29-3.62$ & $2.31-3.44$ \\
\hline & M & $70-90$ & 9.25 & 85.97 & $3.62-5.56$ & $3.44-5.09$ \\
\hline
\end{tabular}

Table 7. Regression equation of $\mathrm{P}$ content in the shoot of $U$. humidicola cv. Common as dependent variables of $\mathrm{P}_{2} \mathrm{O}_{5}$ applied to YL and GH soil and critical phosphorous levels in the plant.

\begin{tabular}{cccccc}
\hline Soil & Equation (P content) & $\mathbf{R}^{2}$ & Equation (P accumulation) & $\mathbf{R}^{\mathbf{2}}$ & Critical level in the plant (g kg $^{-1}$ ) \\
\hline $\mathrm{YL}$ & $\hat{\mathrm{Y}}=0.3116+0.0103^{* * P}$ & 0.99 & $\hat{Y}=1.1729+0.1195^{* * P}$ & 0.99 & 1.20 \\
$\mathrm{GH}$ & $\hat{Y}=0.3440+0.0095^{* * P}$ & 0.99 & $\hat{Y}=-1.0138+0.1656^{* * P}$ & 0.99 & 1.54 \\
\hline
\end{tabular}

**Significant at $1 \%$ probability. 
these conditions, not wearing away its extraction power due to the high levels of clay and organic matter (Novais et al., 2015; Kabala et al., 2018).

The $P$ extractions by the resin were superior to the Mehlich-1 extractions in the YL (Table 2). The anion exchange resin method includes a longer stirring time and a saturated sodium bicarbonate solution, which extracts the $\mathrm{P}$ adsorbed onto colloidal surfaces until an electrochemical balance is achieved between the soil and resin surfaces (Bortolon et al., 2011). The extraction process enables evaluating the P-labile fraction by gradual dissolution of soil phosphate compounds and transfer of orthophosphate ions to resin (Silva, 2009). In this case, the high clay and organic matter levels in YL did not influence the extraction power of the resin, obtaining higher levels of $P$ than Mehlich-1. The resin obtained lower $P$ levels in relation to $\mathrm{GH}$, as this soil is characterized by presenting a clay texture and low organic matter levels (Table 1), and the acid extractors more effectively extracted the $P$ levels available in the soil under these conditions.

Dry matter production of $U$. humidicola cv. Common as a function of $P$ doses

Higher SDM productions were obtained in higher doses of $\mathrm{P}_{2} \mathrm{O}_{5}$. $\mathrm{P}$ influences root growth and tillering (Taiz et al., 2017), and the low level causes low dry matter production due to reduced leaf emission and tillering (Martins et al., 2015). Lower phosphate doses promoted lower dry matter production. $P$ deficiency in plants promotes a reduction in the expansion and number of leaves, with its most significant effects (Taiz et al., 2017).

The productivity values reflect a higher production potential at the beginning of the plant's growth phase, because the dry matter productivity in $\mathrm{C}_{1}$ was higher than $\mathrm{C}_{2}$ with a lower phosphate dose in both soils (Table 3 ). U. humidicola was being established in $C_{1}$, thus requiring $P$ content in the soil for its growth, development and tillering, contributing to greater dry matter production (Martins et al., 2015). The phosphate applied to the soil in $\mathrm{C}_{2}$ was possibly absorbed by the plants in $C_{1}$ and adsorbed to soil particles, decreasing its available contents in the soil, and therefore reflecting in lower dry matter production in $\mathrm{C}_{2}$. Plants reduce cell division and production in conditions with low $\mathrm{P}$ availability in the soil, or signs of $P$ deficiency, in addition to decreasing the average length of the cell division zone in the leaves, significantly affecting cell expansion (Taiz et al., 2017).

\section{Selection of extractors}

The nutrient content available in the soil provides variations in the plant growth. Its availability depends on the climatic conditions, the availability of other nutrients and the capacity of the plant's root system to absorb the nutrients (Cantarutti et al., 2007). The nutrient content in the soil does not normally represent the amount absorbed by the plant, and the amount absorbed is a fraction which can be greater or less than the content available in the soil (Alvarez, 1996).
The nutrient content extracted by the different extraction methods will be an indication of availability if it presents a positive correlation with the plant indicators. In the case of extractor selection, the correlation between the P levels in the soil and the $P$ accumulation in the plant is used. The results of this study demonstrate that all extractors were efficient in predicting the $\mathrm{P}$ availability in the soil, as they presented a strong correlation (0.8-1) as described by Evans (1996).

Despite the efficiency of all extractors, we recommend Mehlich-3 because it is a multi-element extractor, it has applicability in different soil types and efficiently extracts $P$ linked to the $\mathrm{Ca}, \mathrm{Al}$ and Fe fractions (Shuai et al., 2016), which are characteristics found in Amazon soils (Table 1). The anion exchange resin is a laborious method, presenting a problem in the sample crushing stages, extraction of $\mathrm{P}$ by percolation and also due to the excessive stirring time, leading to this method not being used in most routine soil analysis labs (Raij et al., 1986). Among the extractors used, Mehlich-1 presented the lowest correlation coefficients $r=0.86$ for $\mathrm{YL}$ and 0.85 for $\mathrm{GH}$; therefore, Mehlich-1 was considered the least efficient for this study. Mehlich-1 has its extraction efficiency reduced in soils with high clay and organic matter levels, in addition to extracting more of the $\mathrm{P}$ fractions linked to $\mathrm{Ca}$ in relation to $\mathrm{Al}$ and $\mathrm{Fe}$, being able to obtain lower correlations between the $P$ levels in the soil and $\mathrm{P}$ accumulation in the plant.

Critical levels and fertility classes of $P$ for Mehlich-1, Mehlich-3 and anion exchange resin extractors

The construction of diagnostic fertilizer and recommendation models consists of correlation and calibration studies of soil analysis methods. The calibration aims to define the critical levels and relate the nutrient content extracted by the extractors and the plants' response to the nutrient doses. The critical level is conceptualized as the nutrient content in the soil extracted by soil analysis methods which classify soils with low and high probability of response to fertilization, or it can also be defined as the nutrient content in the soil that determines the maximum economic efficiency (MEE) (Cantarutti et al., 2007).

The highest critical levels were obtained by the Mehlich-3 extractor due to its high efficiency in extracting the $P$ linked to the forms of P-Ca, P-Al and P-Fe. The greater capacity of Mehlich-3 extraction reflects higher $P$ levels in the fertility classes (Wuenscher et al., 2015). The levels which define the availability classes vary according to the extractor's sensitivity to soil attributes. We can observe that the critical levels and the fertility classes presented divergent values because each extractor has a specific chemical composition and extract different fractions of $\mathrm{P}$ in the soil.

Calibrating $P$ doses aims to facilitate interpretation of soil analysis results. Having defined the critical levels and fertility classes for Mehlich-1, Mehlich-3 and anion exchange resin, and in possession of the chemical analysis of the soil from producers who cultivate $U$. humidicola, we can recommend the dose to achieve MEE in YL and GH (Tables 5 and 6). 
Critical P levels in the plant

We estimated the critical levels for $U$. humidicola through the applied doses. The critical $P$ levels are within the recommended values, with $P$ contents in the plant varying between 1 and $5 \mathrm{~g} \mathrm{~kg}^{-1} \mathrm{P}$ (Cantarutti et al., 2007). We can assess the nutritional status of cultivars produced by farmers in Amazonas based on the estimated critical level. Values below the critical level determined in this study, the plant will respond positively to the application of phosphate fertilizers. However, there will be no need to apply phosphate fertilizers for values above the critical level.

Based on the results of this study, we accept the tested hypothesis with lower Mehlich-1 efficiency being found in soils with a high clay and organic matter content, such as YL. It is possible to infer that the analyzed soils present scarce amounts of $P$ available to be used by forages. This may be one of the limiting factors for the establishment of forage in Amazon soils. The critical levels and classes of soil fertility in Amazonas are incompatible with other regions in Brazil, therefore requiring further studies with an extraction solution to evaluate the $P$ availability in the soil, looking for a more efficient method to represent the real role of the plant. Thus, it will be possible to recommend more accurate $P$ doses. However, based on the results we recommend Mehlich-3 as the soil analysis method for future field studies to estimate the $\mathrm{P}$ availability.

\section{Conclusions}

All extractors are efficient in assessing the $P$ availability in $\mathrm{YL}$ and $\mathrm{GH}$ soils. The clay and organic matter content negatively affects Mehlich-1 efficiency. The anion exchange resin extraction is not affected by soil characteristics. We recommend Mehlich-3 for more efficiently extracting $P$ fractions from Amazon soils.

The critical soil level for establishing $U$. humidicola cv. Common determined by Mehlich-3 in YL is $10.32 \mathrm{mg} \mathrm{dm}^{-3}$ of $P$ and in $\mathrm{GH}$ it is $7.46 \mathrm{mg} \mathrm{dm}^{-3}$ of $P$. The critical level in plants grown in $\mathrm{YL}$ is $1.20 \mathrm{mg} \mathrm{dm}^{-3}$ of $\mathrm{P}$, and it is $1.54 \mathrm{mg} \mathrm{dm}^{-3}$ of $\mathrm{P}$ in $\mathrm{GH}$.

Soil phosphate doses may be recommended based on $\mathrm{P}$ fertility classes to achieve $P$ levels and the desired relative production for cultivating $U$. humidicola cv. Common in $\mathrm{YL}$ and $\mathrm{GH}$. The results of this study may serve as a reference for future research on correlating the $\mathrm{P}$ dose calibration.

\section{Compliance with Ethical Standards}

Funding: This study was financed in part by the Coordenação de Aperfeiçoamento de Pessoal de Nível Superior-Brasil (CAPES) and published with the financed support of Programa de Apoio à Pós-Graduação stricto sensu of the Fundação de Amparo à Pesquisa do Estado do Amazonas(POSGRAD2019/ FAPEAM).

Conflict of interest: Authors declare that there is no conflict of interest that may influence the article, which may be published.
Author contribution: Conceptualization: NUNES, MT; TUCCI, CAF; DIAS, FJ; Data curation: NUNES, MT; Formal analysis: NUNES, MT; Funding acquisition: NUNES, MT; TUCCI, CAF; Investigation: NUNES, MT; MARTINS, RRS; Methodology: NUNES, MT; TUCCI, CAF; DIAS, FJ; Project administration: NUNES, MT; TUCCI, CAF; DIAS, FJ; Resources: TUCCI, CAF; DIAS, FJ; Supervision: NUNES, MT; TUCCI, CAF; DIAS, FJ; Validation: NUNES, MT; TUCCI, CAF; Visualization: NUNES, MT; Writing - original draft: NUNES, MT; TUCCI, CAF; DIAS, FJ; NEGREIROS, TMN; Writing - review \& editing: NUNES, MT; NEGREIROS, TMN; BRITO, WBM.

\section{Literature Cited}

Alvarez, V.H. Correlação e calibração de métodos de análise de solos. In: Alvarez, V.H.; Fontes, L. E. F.; Fontes, M. P. F. (Eds.). O solo nos grandes domínios morfoclimáticos do Brasil e o desenvolvimento sustentado. 1.ed. Viçosa: SBCS; UFV,1996. p.615-646.

Arruda, E.M.; Maria, R.; Lana, Q.; Pereira, H. S. Fósforo extraído por Mehlich I e resina de troca aniônica em solos submetidos á calagem. Bioscience Journal, v.31, n.4, p.1107-1117, 2015. https://doi.org/10.14393/bj-v31n4a2015-22170.

Bortolon, L.; Gianello, C.; Welter, S.; Almeida, R.G.O.; Giasson, E. Simultaneous extraction of phosphorus, potassium, calcium and magnesium from soils and potassium recommendations for crops in Southern Brazil. Pedosphere, v.21, n.3, p.365-372, 2011. https://doi.org/10.1016/S1002-0160(11)60137-9.

Brito Neto, J.F.; Büll, L.T.; Da Silva, A.L.P.; Do Vale, L.S.; Rigon, J.P.G. Critical phosphorus levels and availability for castor oil plant grown in different soil classes of Brazil. Australian Journal of Crop Science, v.11, n.4, p.491-495, 2017. https://doi.org/10.21475/ajcs.17.11.04.7812.

Cantarutti, R.B.; Barros, N.F.; Martinez, H.E.P.; Novais, R.F. Avaliação da fertilidade do solo e recomendação de fertilizantes. In: Novais, R. F.; Alvarez V., V. H.; Barros, N. F.; Fontes, R. L. F. F.; Cantarutti, R. B.; Neves, J. C. L. (Eds.). Fertilidade do solo. Viçosa: Sociedade Brasileira de Ciência do Solo, 2007. p.769-850.

Chang, S.C.; Jackson, M.L. Solubility product of iron phosphate. Soil Science Society of America Journal, v.21, n.3, p.265-269, 1957. https://doi.org/10.2136/sssaj1957.03615995002100030005x.

Evans, J. Straightforward statistics for the behavioral sciences. Pacific Grove: Thomson Brooks; Cole Publishing Company, 1996. 600p.

Freitas, I.F. de; Novais, R.F.; Villani, E.M.A.; Novais, S. V. Phosphorus extracted by ion exchange resins and Mehlich-1 from oxisols (latosols) treated with different phosphorus rates and sources for varied soil-source contact periods. Revista Brasileira de Ciência do Solo, v.37, n.3, p.667-677, 2013. https://doi.org/10.1590/ s0100-06832013000300013.

Gou, X.; Cai, Y.; Wang, C.; Li, B.; Zhang, Y.; Tang, X.; Shen, J.; Cai, Z. Effects of different long-term cropping systems on phosphorus adsorption and desorption characteristics in red soils. Journal of Soils and Sediments, v.20, n.3, p.1371-1382, 2020. https://doi. org/10.1007/s11368-019-02493-2.

Kabala, C.; Galka, B.; Labaz, B.; Anjos, L.; Souza, R. Towards more simple and coherent chemical criteria in a classi fi cation of anthropogenic soils: A comparison of phosphorus tests for diagnostic horizons and properties. Geoderma, v.320, p.1-11, 2018. https://doi.org/10.1016/j.geoderma.2018.01.024. 
Malavolta, E. Elementos de nutrição mineral de plantas. São Paulo: Agronômica Ceres, 1980. 251p.

Martins, L.E.C.; Monteiro, F.A.; Pedreira, B.C. Photosynthesis and leaf area of Brachiaria brizantha in response to phosphorus and zinc nutrition. Journal of Plant Nutrition, v.38, n.5, p.754-767, 2015. https://doi.org/10.1080/01904167.2014.939758.

Mumbach, G.L.; Gatiboni, L.C.; Dall'orsoletta, D.J.; Schmitt, D.E.; Pessotto, P.P.; Oliveira, C.M.B. Phosphorus extraction with soil test methods affected by soil $P$ sorption capacity. Journal of Soil Science and Plant Nutrition, 2020. https://doi.org/10.1007/ s42729-020-00259-1.

Mumbach, G.L.; Oliveira, D.A.; Warmling, M.I.; Gatiboni, L.C. Quantificação de fósforo por Mehlich 1, Mehlich 3 e resina trocadora de ânions em solos com diferentes teores de argila. Revista Ceres, v.65, n.6, p.546-554, 2018. https://doi. org/10.1590/0034-737x201865060010.

Novais, S.V.; Mattiello, E.M.; Vergutz, L.; Melo, L.C.A.; De Freitas, Í.F.; Novais, R.F. Loss of extraction capacity of mehlich-1 and monocalcium phosphate as a variable of remaining $p$ and its relationship to critical levels of soil phosphorus and sulfur. Revista Brasileira de Ciência do Solo, v.39, n.4, p.1079-1087, 2015. https://doi.org/10.1590/01000683rbcs20140551.

Raij, B.V.; Quaggio, J.A.; Da Silva, N.M. Extraction of phosphorus, potassium, calcium, and magnesium from soils by an ionexchange resin procedure. Communications in Soil Science and Plant Analysis, v.17, n.5, p.547-566, 1986. https://doi. org/10.1080/00103628609367733.

Ribeiro, A.C.; Guimarães, P.T.G.; Alvarez, V.H. (Eds.). Comissão de fertilidade do solo do Estado de Minas Gerais. Recomendações para uso de corretivos e fertilizantes em Minas Gerais: 5a aproximação. Viçosa: Comissão de Fertilidade do Solo do Estado de Minas Gerais, 1999. 359p.
Rosan, S.D.; Silva, C.A.; Maluf, H.J.G.M. Humic acid-phosphate fertilizer interaction and extractable phosphorus in soils of contrasting texture. Revista Ciência Agronômica, v.49, n.1, p.3242, 2018. https://doi.org/10.5935/1806-6690.20180004.

Santos, H.G. dos; Jacomine, P.K.T.; Anjos, L.H.C.; Oliveira, V.A. de; Oliveira, J.B.; Coelho, M.R.; Lumbreras, J.F.; Cunha, T.J.F. (Eds.). Sistema brasileiro de classificação de solos. 2.ed. Rio de Janeiro: Embrapa Solos, 2006. 306p.

Schaefer, C.E.G.R.; Fabris, J.D.; Ker, J.C. Minerals in the clay fraction of Brazilian Latosols (Oxisols): a review. Clay Minerals, v.43, n.1, p.137154, 2008. https://doi.org/10.1180/claymin.2008.043.1.11.

Shuai, X.; Li, X.; S. Yost, R.; Wendroth, O. State-space estimation of the intrinsic soil phosphorus pools from the Mehlich-3 test. Communications in Soil Science and Plant Analysis, v.47, n.8, p.1058-1068, 2016. https://doi.org/10.1080/00103624.2016.11 66244.

Silva, F.C.D.S. (Ed.). Manual de análises químicas de solos, plantas e fertilizantes. Brasília: Embrapa Informação Tecnológica; Rio de Janeiro: Embrapa Solos, 2009. 627p.

Taiz, L.;Zeiger, E.; Møller, I. M.; Murphy, A. Fisiologia e desenvolvimento vegetal. 6.ed. Porto Alegre: Artmed, 2017. 858p.

Wu, Q.; Zhou, W.; Chen, D.; Cai, A.; Ao, J.; Huang, Z. Optimizing soil and fertilizer phosphorus management according to the yield response and phosphorus use efficiency of sugarcane in southern China. Journal of Soil Science and Plant Nutrition, 2020. https:// doi.org/10.1007/s42729-020-00236-8.

Wuenscher, R.; Unterfrauner, H.; Peticzka, R.; Zehetner, F. A comparison of 14 soil phosphorus extraction methods applied to 50 agricultural soils from Central Europe. Plant, Soil and Environment, v.61, n.2, p.86-96, 2015. https://doi. org/10.17221/932/2014-pse. 